\title{
Kinetic modeling of liquid-phase adsorption of Congo red dye using guava leaf-based activated carbon
}

\author{
Adedamola Titi Ojedokun ${ }^{1} \cdot$ Olugbenga Solomon Bello $^{1}$
}

Received: 19 October 2015/Accepted: 27 December 2015/Published online: 8 February 2016

(C) The Author(s) 2016. This article is published with open access at Springerlink.com

\begin{abstract}
Guava leaf, a waste material, was treated and activated to prepare adsorbent. The adsorbent was characterized using Scanning Electron Microscopy (SEM), Fourier Transform Infra Red (FTIR) and Energy-Dispersive X-ray (EDX) techniques. The carbonaceous adsorbent prepared from guava leaf had appreciable carbon content $(86.84 \%)$. The adsorption of Congo red dye onto guava leaf-based activated carbon (GLAC) was studied in this research. Experimental data were analyzed by four different model equations: Langmuir, Freundlich, Temkin and Dubinin-Radushkevich isotherms and it was found to fit Freundlich equation most. Adsorption rate constants were determined using pseudo-first-order, pseudo-second-order, Elovich and intraparticle diffusion model equations. The results clearly showed that the adsorption of CR dye onto GLAC followed pseudo-second-order kinetic model. Intraparticle diffusion was involved in the adsorption process. The mean energy of adsorption calculated from D-R isotherm confirmed the involvement of physical adsorption. Thermodynamic parameters were obtained and it was found that the adsorption of CR dye onto GLAC was an exothermic and spontaneous process at the temperatures under investigation. The maximum adsorption of CR dye by GLAC was found to be $47.62 \mathrm{mg} / \mathrm{g}$. The study shows that GLAC is an effective adsorbent for the adsorption of CR dye from aqueous solution.
\end{abstract}

Olugbenga Solomon Bello

osbello06@gmail.com; osbello@lautech.edu.ng

Adedamola Titi Ojedokun

damolaojedokun@gmail.com

1 Department of Pure and Applied Chemistry, Ladoke Akintola University of Technology, P.M.B 4000 Ogbomoso, Oyo, Nigeria
Keywords Adsorption - Congo red · Guava leaf-based activated carbon (GLAC) · Kinetics · Exothermic .

Thermodynamics

\section{Introduction}

Color is one of the characteristics of an effluent. Wastewater colored with dyes emanating from the production of the dye and its use in the textile and other industries (Allen and Koumanova 2005). It affects the color of water and restricts sunlight penetration thereby reducing photosynthetic activity (Sivaraj et al. 2001; Nacera and Aicha 2006). Dyes are carcinogenic and mutagenic. Generally, they are stable to biological degradation (Sivaraj et al. 2001; Wong and $\mathrm{Yu}$ 1999). It is therefore very important to get rid of them from effluents produced by industries before discharging into the environment. Congo red is the sodium salt of benzidinediazobis-1-naphthylamine-4-sulfonic acid. It is a benzidine-based azo dye. It was selected in this study as a model anionic dye due to its high solubility in aqueous solution and its persistence once it is discharged into natural environment. It mainly occurs in the effluents discharged from textile, paper, printing, leather industries, etc. (Bhattacharrya and Sharma 2004). While dying, about $15 \%$ of it ends up in waste waters (Srivastava et al. 1988). It is a mutagen and reproductive effector. It acts as a skin, eye and gastrointestinal irritant. Congo red also causes the blood to clot and it is also responsible for aiding somnolence and respiratory problems (Alok et al. 2009). Existing techniques which had been used for removing dyes from wastewater polluted with dyes are disadvantageous due to high cost, the formation of harmful products and consumption of high

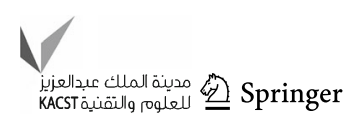


energy (Banat et al. 1996).These techniques include ozonation, coagulation/flocculation, oxidative techniques, precipitation, ion exchange, reverse osmosis and ultra filtration. The commonest treatment (which adopts both physical and chemical methods) for removing dissolved organics from wastewaters is activated carbon adsorption. List of non-conventional, low-cost adsorbents that have been utilized for the removal of dyes from wastewater include durian seed (Ahmad et al. 2014a, b), banana stalk (Bello et al. 2012), wheat husk (Gupta et al. 2007), coconut shell (Bello and Ahmad 2012), periwinkle shell (Bello et al. 2008), Indian spinach leaf, bottom ash and de-oiled soya (Gupta et al. 2006a, 2009; Mittal et al. 2008), hen feathers (Gupta et al. 2006b), oil palm fruit (Bello 2013), mango leaf (Bello et al. 2014), lime peel (Ahmad et al. 2015), spear grass (Bello and Semire 2012), ackee apple (Bello et al. 2013). Commercial activated carbon (CAC) are widely distributed because they are used for a variety of applications, because they are expensive, low cost nonconventional adsorbents is an economical alternative that could be used in lieu of CAC for wastewater treatment.

Guava (Psidium guajava) belongs to the family Myrtaceae. It is a tropical plant usually found growing in backyards and dumpsites. The raw guava leaves contain $6 \%$ fixed oil, and $0.365 \%$ volatile oil, $3.15 \%$ resin, $8.5 \%$ tannin, and other substances. It's seeds and leaves possess medicinal value and are used as traditional herbs for treating ailments (Anthony 2005).

The feasibility of using activated carbon prepared from guava leaf powder for the removal of Congo red (CR), a toxic dye, from wastewater by adsorption method was investigated in this study. The effects of operational factors such as initial dye concentration, contact time and temperature were investigated. The kinetics of $\mathrm{CR}$ dye adsorption was analyzed by fitting to pseudo-first-order, pseudo-second-order, Elovich and intraparticle diffusion models. Adsorption data were also fitted using Langmuir, Freundlich, Tempkin and D-R isotherm equations.

\section{Materials and methods}

\section{Activated carbon preparation}

Guava leaves were obtained from LAUTECH farmland, Ogbomoso, Nigeria. A carefully weighed $25.0 \mathrm{~g}$ of the adsorbent was placed in a beaker containing $500 \mathrm{~cm}^{3}$ of $0.3 \mathrm{~mol} / \mathrm{dm}^{3}$ ortho-phosphoric acid $\left(\mathrm{H}_{3} \mathrm{PO}_{4}\right)$. The content of the beaker was thoroughly mixed and heated to form a paste. The paste formed was then transferred into an evaporating dish which was placed in the furnace and heated to $300{ }^{\circ} \mathrm{C}$ for $30 \mathrm{~min}$. This was allowed to cool and washed with distilled water to a $\mathrm{pH}$ of 6.8 , oven dried for
$4 \mathrm{~h}$ at temperature $105^{\circ} \mathrm{C}$. It was then ground to powder. It was sieved with $106 \mu \mathrm{m}$ mesh to obtain fine powdered activated carbon which was kept in an air-tight container and used for other experiments.

\section{Adsorbate used}

Congo red (CR) dye was used as adsorbate to determine the adsorption performance of the prepared activated carbon (Fig. 1). The properties of CR dye used are listed in Table 1 .

\section{Preparation of Congo red dye solution}

$0.5 \mathrm{~g}$ of Congo red dye was dissolved in $600 \mathrm{~mL}$ of distilled water. Sufficient distilled water was added with constant stirring to make it up to $1000 \mathrm{~mL}$ mark. The other solutions used for the experiment were prepared from the stock solution using serial dilution.

\section{Batch equilibrium studies}

Adsorption of Congo red dye (CR) on GLAC was carried out by batch method at 30,40 and $50{ }^{\circ} \mathrm{C}$ respectively. The effects of initial concentration of the dye, contact time as well as temperature were investigated. The adsorption process was carried out with five different initial concentrations at 10, 20, 30, 40 and $50 \mathrm{mg} / \mathrm{L}$ of CR dye. $10 \mathrm{mg}$ of adsorbent was taken in 250-mL Erlenmeyer flask. $20 \mathrm{~mL}$ of CR dye solution was added to the flask. $\mathrm{pH}$ of the solutions were brought to 3 by adding $0.1 \mathrm{M}$ hydrochloric acid. Sample solutions were withdrawn at predetermined time intervals after shaking in water bath shaker at $120 \mathrm{rpm}$ to determine the quantity of the dye removed from the solution. Concentrations of dye solutions were calculated by determining absorbance at a wavelength of $497 \mathrm{~nm}$ using UV-Vis spectrophotometer.

The amount of CR adsorbed was calculated by:

$\mathrm{q}_{e}=\frac{\left(C_{0}-C_{e}\right)}{m} V$

where $\mathrm{q}_{e}$ is the amount of dye adsorbed by the activated carbon, $\mathrm{C}_{0}$ is the initial concentration of the adsorbate, $\mathrm{C}_{e}$ is the concentration of the adsorbate solution at equilibrium, $m$ is the amount of adsorbent $(\mathrm{g})$ and $V$ is the volume of solution $\left(\mathrm{dm}^{3}\right)$.

\section{Adsorption isotherm studies}

To carry out the adsorption isotherm studies, the equilibrium data were fitted to the Langmuir, Freundlich, Temkin and Dubinin-Radushkevich isotherms. The applicability and suitability of the isotherm equation to the equilibrium 
Table 1 Physicochemical characteristics of Congo red dye

\begin{tabular}{ll}
\hline CAS no. & $573-58-0$ \\
CA index name & 1-Naphthalenesulfonic acid, 3,3'-[(1,1'-biphenyl)-4,4'-diylbis(2,1-diazenediyl)]bis[4 amino-, sodium salt (1:2)] \\
Molecular formula & $\mathrm{C}_{32} \mathrm{H}_{22} \mathrm{~N}_{6} \mathrm{Na}_{2} \mathrm{O}_{6} \mathrm{~S}_{2}$ \\
Molecular weight & $696.66 \mathrm{~g} \mathrm{~mol}^{-1}$ \\
Physical form & Brownish-red powder \\
Molecular surface area & $557.6 \AA^{2}$ \\
Solubility & Soluble in water, ethanol; very slightly soluble in acetone; practically insoluble in ether, xylene \\
Melting point & $>360{ }^{\circ} \mathrm{C}$ \\
pH range & $3.0-5.0$ \\
Color & $\mathrm{Blue}(\mathrm{pH} \mathrm{3.0)}$ to red (pH 5.0) \\
pKa & $4.1 ; 3.0$ \\
Absorption wavelength $\left(\lambda_{\text {max }}\right)$ & $497 \mathrm{~nm}$ \\
\hline
\end{tabular}

data were determined using the values of the correlation coefficients, $R^{2}$. Linear regression was carried out using Microsoft Excel spreadsheet.

\section{Langmuir isotherm}

According to the Langmuir isotherm, the intermolecular forces rapidly decrease as the distance increases. This model helps in predicting the existence of monolayer coverage of the adsorbate on the outer surface of adsorbent. According to Langmuir 1918, the linear form of the isotherm equation is given by:

$\frac{\mathrm{C}_{e}}{\mathrm{q}_{e}}=\frac{1}{\mathrm{q}_{m}} \mathrm{C}_{e}+\frac{1}{\mathrm{~K}_{L} \mathrm{q}_{m}}$,

where $\mathrm{C}_{e}$ is the concentration of the adsorbate at equilibrium $(\mathrm{mg} / \mathrm{L}) ; \mathrm{q}_{e}$, the amount of adsorbate adsorbed per unit mass of adsorbent $(\mathrm{mg} / \mathrm{g}) ; \mathrm{q}_{m}$, the maximum monolayer adsorption capacity of the adsorbent $(\mathrm{mg} / \mathrm{g}) ; \mathrm{K}_{L}$, the Langmuir adsorption constant (L/mg).

The constant value can be determined from intercept and slope of the graph of $\mathrm{C}_{e} / \mathrm{q}_{e}$ against $\mathrm{C}_{e}$. The essential characteristics of Langmuir equation can be expressed in terms of $\mathrm{R}_{L}$ (separator factor) which is dimensionless and it is defined as:

$\mathrm{R}_{L}=\frac{1}{1+\mathrm{K}_{L} \mathrm{C}_{\mathrm{o}}}$

where $\mathrm{C}_{0}$ is the highest initial solute concentration; whereas, $\mathrm{R}_{L}$ value implies the adsorption is unfavorable $\left(\mathrm{R}_{L}>1\right)$, linear $\left(\mathrm{R}_{L}=1\right)$, favorable $\left(0<\mathrm{R}_{L}<1\right)$, or irreversible $\left(\mathrm{R}_{L}=0\right)$.

\section{Freundlich isotherm}

The Freundlich model is based on adsorption on heterogeneous surface or surface supporting sites of varied affinities. It assumes that the stronger binding sites are occupied first and that the binding strength decreases as the rate at which the sites are occupied increases. The Freundlich isotherm (Freundlich 1906) is expressed as:

$\ln \mathrm{q}_{e}=\frac{1}{n} \ln \mathrm{C}_{e}+\ln \mathrm{K}_{F}$,

where $\mathrm{q}_{e}$ is the amount of adsorbate adsorbed per unit mass of adsorbent $(\mathrm{mg} / \mathrm{g}) ; \mathrm{K}_{F}$, Freundlich isotherm constant $\left.(\mathrm{mg} / \mathrm{g})(\mathrm{L} / \mathrm{mg})^{1 / \mathrm{n}}\right) ; \mathrm{C}_{e}$, equilibrium concentration of the adsorbate $(\mathrm{mg} / \mathrm{L}) ; n$, the heterogeneity factor.

If the plot of $\left(\log \mathrm{q}_{e}\right)$ against $\left(\log \mathrm{C}_{e}\right)$ gives a straight line, it shows that the Freundlich isotherm fits the adsorption data. Other constants can be calculated from $1 / n$ (the slope) and $\log \mathrm{K}_{F}$ (the intercept) obtained from the graph. The slope of $1 / n$ ranging between 0 and 1 is a measure of adsorption intensity, becoming more heterogeneous as its value gets closer to zero.

\section{Temkin isotherm}

Temkin isotherm considers the adsorbent-adsorbate interactions. It assumes a linear decrease in the heat of adsorption of molecules with coverage due to adsorbentadsorbate relationships. According to Temkin and Pyzhev 1940, the Temkin model is expressed as:

$\mathrm{q}_{e}=\mathrm{B} \ln \left(\mathrm{K}_{T} \mathrm{C}_{e}\right)$

This can be rearranged to:

$\mathrm{q}_{e}=\mathrm{B} \ln \mathrm{K}_{T}+\mathrm{B} \ln \mathrm{C}_{e}$,

where $B=R T / b$ is the constant related to the heat of adsorption $(\mathrm{L} / \mathrm{mg}) ; \mathrm{q}_{e}$, the amount of adsorbate adsorbed at equilibrium $(\mathrm{mg} / \mathrm{g}) ; \mathrm{C}_{e}$, equilibrium concentration of adsorbate $(\mathrm{mg} / \mathrm{L}) ; T$, absolute temperature; $R$, universal gas constant $(8.314 \mathrm{~J} / \mathrm{mol} \mathrm{K}) ; \mathrm{K}_{T}$, equilibrium binding constant $(\mathrm{L} / \mathrm{mg})$. 
A graph of plot of $\mathrm{q}_{e}$ versus $\ln \mathrm{C}_{e}$ yields a straight line from where both values of slope, $B$ and intercept, $\mathrm{K}_{T}$ will be calculated.

\section{Dubinin-Radushkevich isotherm}

Dubinin-Radushkevich isotherm is applied to differentiate between the physical and chemical adsorption for the removal of a molecule from its location in the adsorption space to the infinity. It is expressed as (Dubinin 1960):

$\mathrm{q}_{\mathrm{e}}=\mathrm{q}_{\mathrm{m}} \exp \left(-\mathrm{K}_{\varepsilon^{2}}\right)$

where:

$\delta=\mathrm{RT}\left[1+1 / \mathrm{C}_{\mathrm{e}}\right]$

$\mathrm{q}_{e}$ is the amount of adsorbate adsorbed at equilibrium; $\mathrm{q}_{m}$, maximum adsorption capacity; $B$, Dubinin-Radushkevich constant; $R$, gas constant; $T$, absolute temperature; $\mathrm{C}_{e}$, equilibrium concentration of adsorbate.

Therefore, a graph of $\ln q_{e}$ against $\delta^{2}$ will give a straight line with the slope of $B$ and intercept of $\ln \mathrm{q}_{m}$. Also, from the value of $B$, the free energy of sorption per molecule of the adsorbate, $E$, can be determined by using the equation:

$\mathrm{E}=\frac{1}{\sqrt{2 \mathrm{~B}}}$

The adsorption energy $E$ shows the type of adsorption occurring. A value of $E$ ranging from 1 to $8 \mathrm{~kJ} / \mathrm{mol}$ signifies physical adsorption while a value that ranges from 9 to $16 \mathrm{~kJ} / \mathrm{mol}$ shows that the adsorption is chemical (Ajemba 2014).

\section{Adsorption kinetic studies}

To carry out the adsorption kinetic studies, the adsorbent-adsorbate solution was taken at specific intervals and the concentration of the solution was measured. The amount adsorbed at time $t, \mathrm{q}_{t}(\mathrm{mg} / \mathrm{g})$, was calculated using Eq. 1. The adsorption kinetics of dye on adsorbent was investigated using pseudo-first-order, pseudo-second-order, Elovich and intraparticle diffusion models, respectively.

\section{Pseudo-first order kinetic model}

According to Lagergren 1898, the pseudo-first-order kinetic model equation is expressed as:

$\ln \left(\mathrm{q}_{e}-\mathrm{q}_{t}\right)=\ln \mathrm{q}_{e}-k_{1} t$

where $\mathrm{q}_{e}$ is the amount of concentration of adsorbate at equilibrium $(\mathrm{mg} / \mathrm{g}), \mathrm{q}_{t}$ is the amount of solute adsorb per unit weight of adsorbent at time $t(\mathrm{mg} / \mathrm{g}), k_{1}$ is the rate constant $\left(\min ^{-1}\right)$. A plot of $\ln \left(\mathrm{q}_{e}-\mathrm{q}_{t}\right)$ versus $t$ gives a straight line with slope of $k_{1}$ and intercept of $\operatorname{lnq}_{e}$.

\section{Pseudo-second-order kinetic model}

The equation of the model equation can be expressed as (Ho and McKay 1999):

$\frac{t}{\mathrm{q}_{t}}=\frac{1}{k_{2} \mathrm{q}_{e}^{2}}+\frac{1}{\mathrm{q}_{e}} t$

The slope and intercept of the graph of $t / \mathrm{q}_{t}$ against $t$ give the values of $\mathrm{q}_{e}$ and $k_{2}$, respectively.

\section{Elovich kinetic model}

The equation is expressed as (Aharoni and Ungarish 1976):

$\mathrm{q}_{t}=\left(\frac{1}{\beta}\right) \ln (\alpha \beta)+\frac{1}{\beta} \ln t$

where: $\alpha$ is the the initial rate of desorption $[\mathrm{mg} /(\mathrm{g} \mathrm{min})]$, $\beta$, the desorption constant $(\mathrm{g} / \mathrm{mg})$. The $1 / \beta$ value signifies the number of sites available for adsorption and the value of $(1 / \beta) \ln (\alpha \beta)$ shows the adsorption quantity when $\ln t$ equal to zero.

\section{Intraparticle diffusion model}

Weber and Morris 1962 expressed the intraparticle diffusion model as shown in Eq. 13:

$q_{t}=k_{\mathrm{dif}} t^{1 / 2}+C$

where: $C$ is the the intercept; $K_{\text {dif }}\left(\mathrm{mg} / \mathrm{g} \mathrm{h}^{1 / 2}\right)$, the intraparticle diffusion rate constant; $\mathrm{q}$, the amount of solute adsorbed per unit weight of adsorbent per time $(\mathrm{mg} / \mathrm{g}) ; t_{t}{ }^{1 / 2}$, the half-adsorption time $\left(\mathrm{h}^{1 / 2}\right)$.

The intercept of the plot reflects the boundary layer effect. For intraparticle diffusion to be the only rate-determining step, then the regression of $\mathrm{q}_{t}$ against $t^{1 / 2}$ must be linear and should pass through the origin. If otherwise, then it implies that the intraparticle diffusion is not the only rate-controlling step (Wu et al. 2005).

\section{Thermodynamic studies}

Thermodynamics parameters are used in revealing the type of energy changes that occur in an adsorption process. In order to investigate the adsorption process, three thermodynamic parameters were evaluated. They include

- $\quad$ standard enthalpy change $\left(\Delta H^{\circ}\right)$;

- standard entropy change $\left(\Delta S^{\circ}\right)$; and

- standard free energy change $\left(\Delta G^{\circ}\right)$. 
These values can be calculated by using the following equation:

$\operatorname{Ink}_{L}=\frac{\Delta s^{\circ}}{R}-\frac{\Delta H^{\circ}}{R T}$,

where: $\mathrm{k}_{L}$ is the Langmuir adsorption constant $(\mathrm{L} / \mathrm{mol})$; $\Delta S^{\circ}$, changes in standard entropy $(\mathrm{kJ} / \mathrm{mol} / \mathrm{K}) ; R$, universal gas constant $(8.314 \mathrm{~J} / \mathrm{mol} / \mathrm{K}) ; \Delta H^{\circ}$, changes in standard enthalpy $(\mathrm{kJ} / \mathrm{mol}) ; T$, absolute solution temperature $(\mathrm{K})$.

Thus, a plot of $\ln \mathrm{k}_{L}$ against $1 / T$ yields the values of both $\Delta H^{\circ}$ and $\Delta S^{\circ}$ from the slope and intercept of the graph, respectively. Fundamentally, a positive $\Delta H^{\circ}$ value indicates that an adsorption process is endothermic in nature while a negative value represents exothermic reaction.

A positive value of $\Delta S^{\circ}$ indicates an increment in randomness at the solid/solution interface that occurs in the adsorption process besides reflecting the affinity of the adsorbent toward the adsorbate (Bello et al. 2011). Furthermore, a negative $\Delta G^{\circ}$ value indicates that an adsorption process is a spontaneous process at the study temperature and vice versa. $\Delta G^{\circ}$ can be calculated using the following relation:

$\Delta G^{\circ}=-R T \ln \mathrm{K}_{L}$

As the nature of adsorption is determined by the magnitude of activation energy, $\mathrm{E}_{a}$, Arrhenius equation has been applied to determine either the process is physical or chemical. Physisorption process has the activation energy ranging from 5 to $40 \mathrm{~kJ} / \mathrm{mol}$. For chemisorption process, the activation energy is higher and ranging from 40 to $800 \mathrm{~kJ} / \mathrm{mol}$ (Nollet et al. 2003). As shown in the following relationship, Arrhenius equation can be represented by:

$\ln k_{2}=\ln A-\frac{\mathrm{E}_{a}}{R T}$,

where $k_{2}$ is the rate constant obtained from the pseudosecond-order kinetic model $(\mathrm{g} / \mathrm{mg} \mathrm{h}) ; A$, the Arrhenius factor; $\mathrm{E}_{a}$, the Arrhenius activation energy of adsorption $(\mathrm{kJ} / \mathrm{mol}) ; R$, the universal gas constant $(8.314 \mathrm{~J} / \mathrm{mol} / \mathrm{K})$; $T$, the absolute temperature $(\mathrm{K})$.

Therefore, a plot of $\ln \mathrm{k}_{2}$ against $1 / T$ will yield the values of $\mathrm{E}_{a}$ from the slope of the graph, $-\mathrm{E}_{a} / R$.

\section{Characterization of adsorbent}

Scanning electron microscope (model JSM-6460 LV, JEOL, Kyoto, Japan) was used to study the pore structure, surface chemistry, and the arrangement of pores of the adsorbent before and after activation. Fourier transform infrared (FTIR) spectroscopic analysis was performed using an FTIR spectrometer (FTIR-2000, Perkin Elmer). The spectra were measured from 4000 to $400 \mathrm{~cm}^{-1}$. EDX analysis (energy-dispersive $\mathrm{X}$-ray analysis) was used to identify the elemental composition of the adsorbent. An energy-dispersive (EDX) detector is used to separate the characteristic X-rays of different elements into an energy spectrum, and EDX system software is used to analyze the energy spectrum in order to determine the abundance of specific elements.

\section{Results and discussion}

\section{Characterization}

\section{Surface morphology}

Scanning electron microscopy (SEM) was used to demonstrate the surface morphology of GLAC. Figure 2 shows the SEM micrograph of GLAC. The surface structures were rough and uneven. It has several pores due to the modification using activating agent. A significant pore structure exists over the surface of the adsorbents. This was due to the breakdown of the lignocellulosic material at high temperature followed by evaporation of volatile compounds leaving samples with well-developed pores. These pores allowed a good surface for CR dye to be trapped and adsorbed into (Amin 2008). During activation process, the $\mathrm{C}-\mathrm{H}_{3} \mathrm{PO}_{4}$ reaction rate was increased, thus resulting in

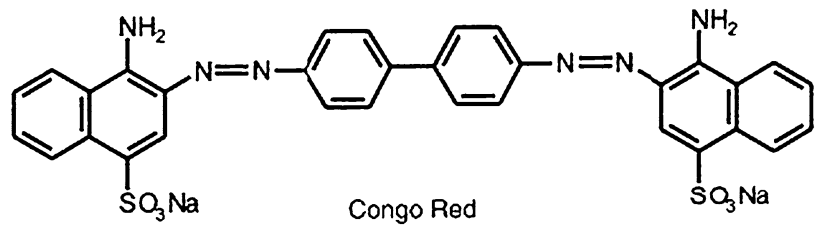

Fig. 1 Structure of Congo red

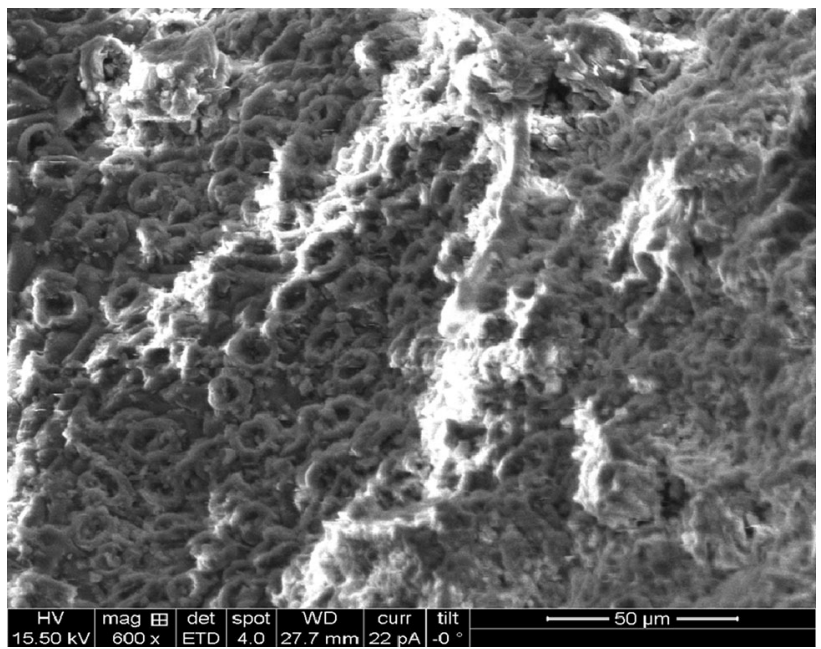

Fig. 2 SEM micrograph of GLAC (magnification $\times 600$ )

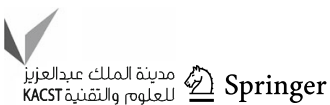


Fig. 3 FTIR spectra of a Raw guava leaf and $\mathbf{b}$ GLAC
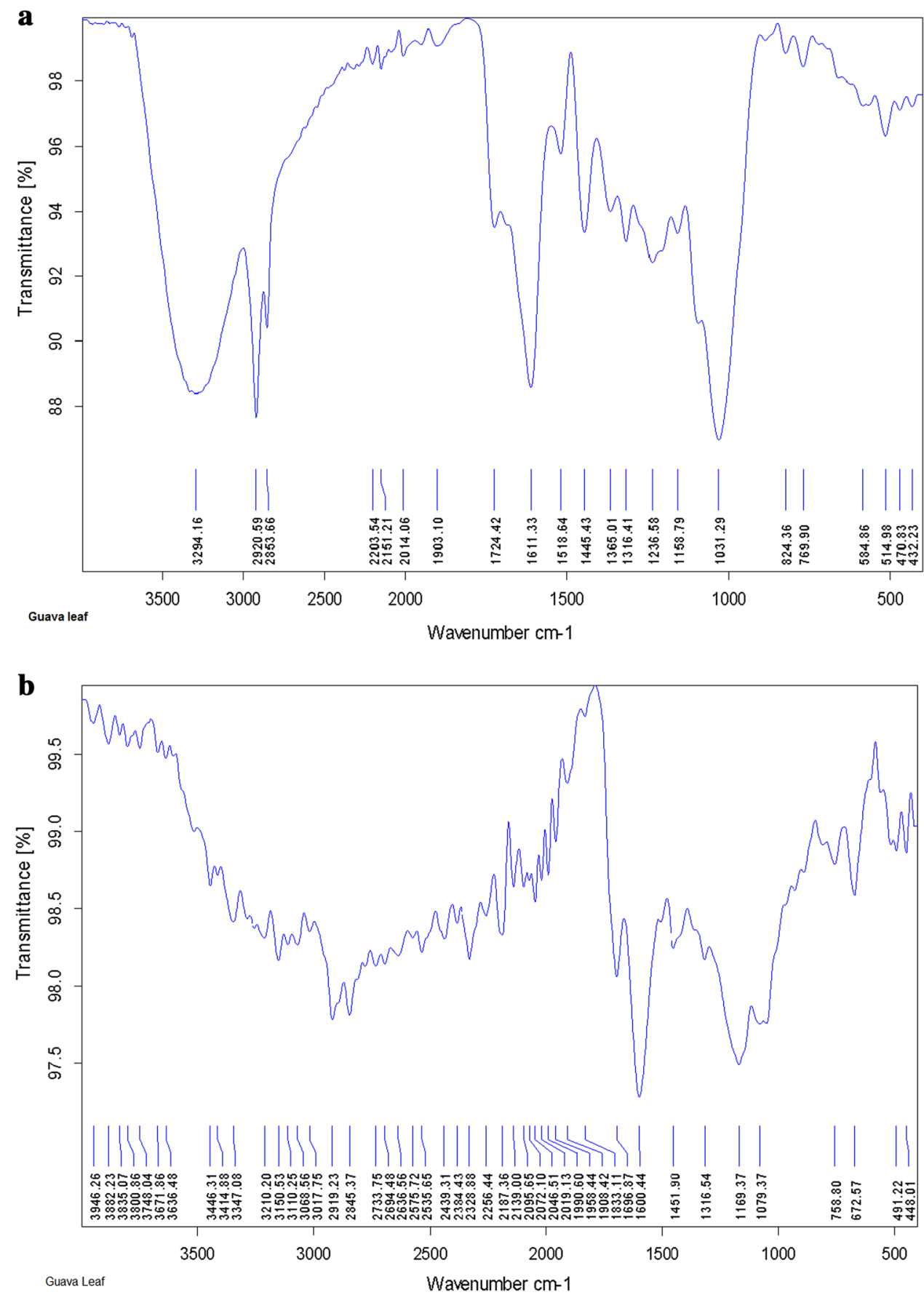

carbon 'burn off' thereby developing good pores on the sample. The $\mathrm{C}-\mathrm{H}_{3} \mathrm{PO}_{4}$ reaction also increased the porosity of the adsorbents as well as creating new pores due to loss of volatile components in the form of $\mathrm{CO}$ and $\mathrm{CO}_{2}$ (Auta and Hameed 2011). The physiochemical treatment was able to produce porous adsorbent thereby increasing the surface area. The activation processes had resulted in enhancement of porous structure of the adsorbents, which contributed to the large surface area. This porous structure of the adsorbents will increase the adsorption capacity of the adsorbent.

\section{Surface chemistry}

In order to investigate the surface chemistry of the sample, Fourier transform infrared spectroscopy (FTIR) analysis was carried out in revealing the presence of several peaks of functional group. The FTIR spectra of the adsorbent before and after activation are shown in Fig. 3. These figures show that some peaks are shifted or disappeared and some new peaks are also detected which may be due to the activation process. FTIR data of GLAC adsorbent are shown in Table 2. 
Table 2 FTIR of GLAC adsorbent

\begin{tabular}{lll}
\hline Frequency $\left(\mathrm{cm}^{-1}\right)$ & & Band assignment \\
\hline Raw guava leaf & GLAC & \\
\hline 3294.16 & 3159.94 & O-H stretch \\
2920.59 & 2924.72 & C-H stretch \\
2203.54 & 2200.62 & C $\equiv$ C stretch \\
1724.42 & 1701.83 & C=O stretch \\
1445.43 & 1459.59 & C-O stretch \\
\hline
\end{tabular}

\section{Elemental composition}

In order to determine the elements present in the guava leaf adsorbent before and after adsorption, the energy-dispersive X-ray (EDX) technique was employed. The EDX spectra and data of the adsorbent are shown in Fig. 4 and Table 3, respectively. From Table 3, it can be deduced that activation of the adsorbent had increased the carbon content of the corn cob adsorbent. This implies that activation will lead to an increase in the adsorption capacity of the adsorbent (Okeola 1999; Dada et al. 2012).

\section{Batch adsorption studies}

\section{The effect of contact time and initial $C R$ dye concentration}

The effect of contact time on adsorption of CR onto GLAC at various initial concentrations $(10-50 \mathrm{mg} / \mathrm{L})$ at $30{ }^{\circ} \mathrm{C}$ is presented in Fig. 5. The adsorption uptake increased with time at the initial stage and became slower before reaching its equilibrium stage. This can be attributed to the fact that there was higher availability of vacant sites on the adsorbents at the initial stage. This developed a strong driving force for dye molecules to overcome the mass transfer resistance between aqueous and solid phases. After a period of time, the remaining surface site became difficult to occupy due to the electrostatic hindrance or repulsive forces that exist between the dye molecules and the surface of adsorbent. At this point, equilibrium was reached. This stage also reflects the maximum adsorption capacity of each adsorbent under certain operating conditions (Bhadusha and Ananthabaskaran 2011).

Apart from this, the time required for adsorption process to reach equilibrium stage strongly depends on the initial dye concentration. At high initial concentration, the concentration of dye adsorbed at equilibrium was high. At $10 \mathrm{mg} / \mathrm{L}$ initial concentration, the maximum adsorption uptake was $9.76 \mathrm{mg} / \mathrm{g}$, whereas for $50 \mathrm{mg} / \mathrm{L}$, the maximum adsorption uptake can reach until $39.70 \mathrm{mg} / \mathrm{g}$ (Fig. 5). At higher initial concentration, the concentration gradient was higher, and in turn developed a higher driving force during the adsorption process. As a result of increased diffusion process, the equilibrium adsorption uptake increased (Baek et al. 2010).

Figure 6 shows the percentage of CR dye removal by GLAC under the same condition. The plot shows that the percentage of dye removal was inversely proportional to the initial dye concentration. The tabular representation is shown in Table 4. The ratio of the molecules of dye to vacant sites becomes smaller at lower initial dye concentration (Fig 6). This indirectly led to higher percentage of dye removal in solution. As the initial concentration increased, the ratio of dye molecules to vacant sites increased and most of the vacant sites become saturated. At this stage, dye molecules tend to compete among themselves to diffuse into the internal pores, resulting in lower percentage of removal.

\section{Adsorption isotherms}

Table 5 shows the parameters of isotherm models employed in this study at $30{ }^{\circ} \mathrm{C}$. The models include: Langmuir, Freundlich, Temkin and Dubinin-Radushkevich. The suitability of the model was determined by choosing the model with the value of $R^{2}$ closest to 1 .

According to theoretical Langmuir adsorption isotherm, it assumes that the maximum monolayer adsorption occurs when the surface is covered by a monolayer of adsorbates. Therefore, by using this isotherm, the maximum adsorption capacity corresponding to the complete monolayer coverage on GLAC can be calculated (Yahya et al. 2008). The mean $\mathrm{q}_{m}$ of GLAC as contained in Tables 5, 6, 7 are 47.62, 45.45 and $40 \mathrm{mg} / \mathrm{g}$ respectively.

Freundlich isotherm is used to illustrate the non-ideal heterogeneous behavior of adsorption process. The extent of adsorption was described by the value of $\mathrm{K}_{F}$. It was found that the extent of adsorption at $50{ }^{\circ} \mathrm{C}\left(\mathrm{K}_{F}=19.36\right)$ was approximately 1.2 times higher than that of $30^{\circ} \mathrm{C}$ $\left(\mathrm{K}_{F}=15.92\right)$. The value of $\mathrm{n}$ calculated from the Freundlich model was greater than 1 . This implies that the change in dye concentration is greater than the change in the dye concentration in solution (Ajemba 2014).

The equilibrium binding constant, $\mathrm{b}_{T}(\mathrm{~mol} / \mathrm{g})$ which is the Temkin isotherm constant, can be determined from the Temkin isotherm model.

The Dubinin-Radushkevich isotherm model was used to examine the porosity apparent free energy, $E$ and the characteristics of the adsorption process. The values of $E$ for GLAC at 30,40 and $50{ }^{\circ} \mathrm{C}$ are $2.41,3.37$ and $3.50 \mathrm{~kJ} / \mathrm{mol}$, respectively. Since all these values range between 1 and $8 \mathrm{~kJ} / \mathrm{mol}$, it indicated that physisorption played a significant role in the adsorption of $\mathrm{CR}$ onto GLAC (Ajemba 2014). 
Fig. 4 EDX spectra of a raw guava leaf and $\mathbf{b}$ activated guava leaf

\section{$\mathbf{a}$}

Coums

$\overline{633}$

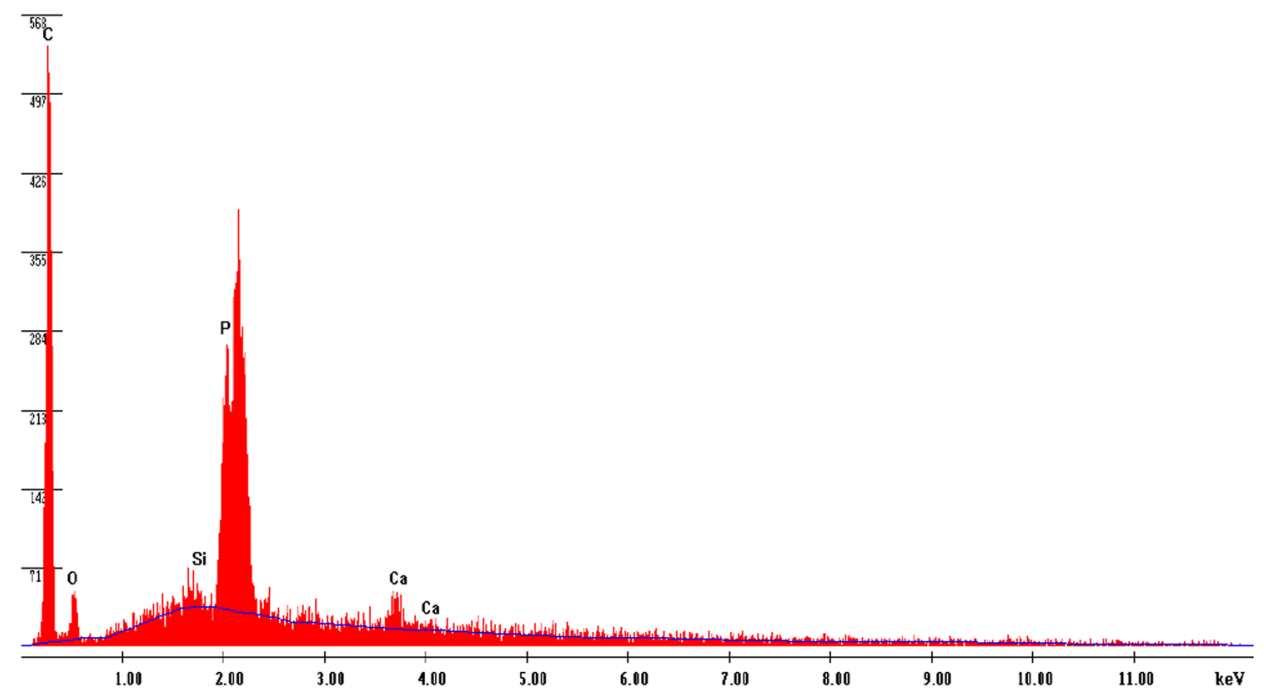

$\underset{\text { bounts }}{\mathbf{b}}$

$\overline{221}$

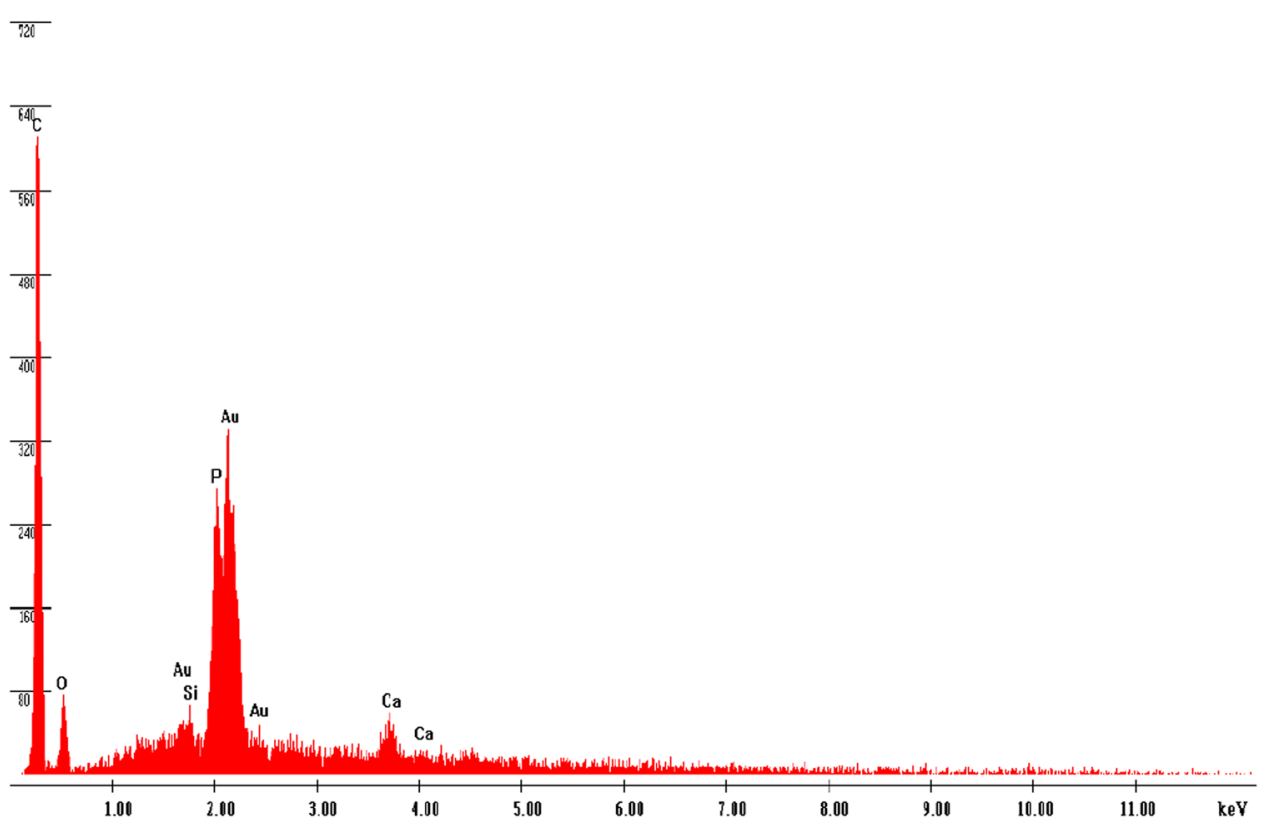

c:|edax32łgenesisłgenspc.spc

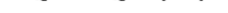

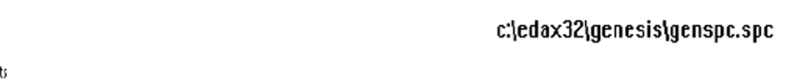

The value of $R^{2}$ was used to judge the most suitable model for the adsorption process. The results obtained were: Temkim $\left(R^{2}=0.937\right)<$ Dubinin-Radushkevich $\left(R^{2}=0.970\right)<$ Langmuir $\quad\left(R^{2}=0.971\right)<$ Freundlich $\left(R^{2}=0.983\right)$ which suggests that the adsorption process was heterogenous and occured by multilayer adsorption.

\section{Separator factor}

Langmuir equation can be expressed in a term of dimensionless separation factor $\left(\mathrm{R}_{L}\right)$. The $\mathrm{R}_{L}$ values obtained ranged from 0 to 1 . This shows that the process was favorable (Bello et al. 2011). Table 8 shows the compar- 
Table 3 (a) EDX data of raw guava leaf; (b) EDX data of GLAC

\begin{tabular}{lll}
\hline Element & Wt. \% & At. \% \\
\hline $\mathrm{a}$ & & \\
$\mathrm{C}$ & 74.09 & 85.86 \\
$\mathrm{O}$ & 6.86 & 5.97 \\
$\mathrm{Si}$ & 1.24 & 0.62 \\
$\mathrm{P}$ & 13.39 & 6.02 \\
$\mathrm{Ca}$ & 4.41 & 1.53 \\
$\mathrm{Total}$ & 100.00 & 100.00 \\
$\mathrm{~b}$ & & \\
$\mathrm{C}$ & 75.06 & 86.84 \\
$\mathrm{O}$ & 5.53 & 4.80 \\
$\mathrm{Si}$ & 0.91 & 0.45 \\
$\mathrm{P}$ & 14.64 & 6.57 \\
$\mathrm{Ca}$ & 3.87 & 1.34 \\
Total & 100.00 & 100.00 \\
\hline
\end{tabular}

Table 4 Percentage of CR dye removal by GLAC at $30{ }^{\circ} \mathrm{C}$

\begin{tabular}{lllll}
\hline$\%$ Removal & & & & \\
\hline $10 \mathrm{mg} / \mathrm{L}$ & $20 \mathrm{mg} / \mathrm{L}$ & $30 \mathrm{mg} / \mathrm{L}$ & $40 \mathrm{mg} / \mathrm{L}$ & $50 \mathrm{mg} / \mathrm{L}$ \\
\hline 97.6 & 91.8 & 89.9 & 85.53 & 79.4 \\
\hline
\end{tabular}

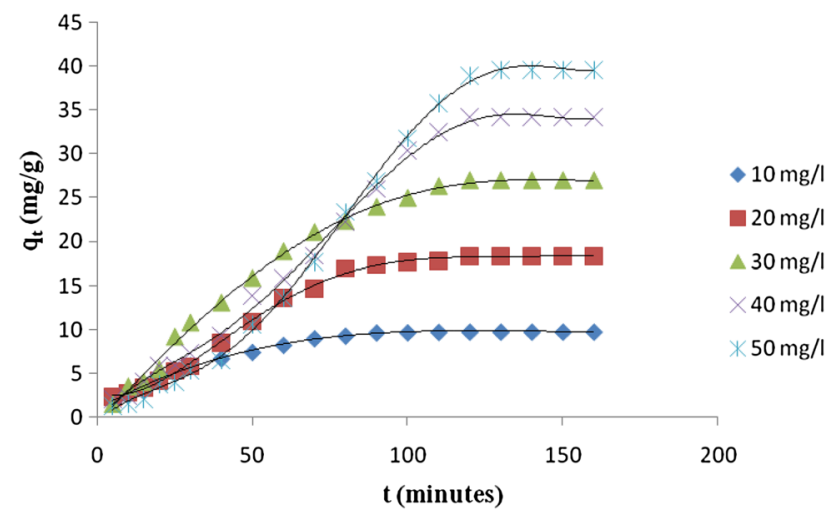

Fig. 5 Plot of adsorption of CR dye onto GLAC against adsorption time at various initial dye concentrations at $30^{\circ} \mathrm{C}$

ison of maximum monolayer adsorption capacities of CR dye unto various adsorbents.

\section{Kinetic studies}

Pseudo-first-order kinetic model is used to predict the adsorption kinetics. Plots of $\ln \left(\mathrm{q}_{e}-\mathrm{q}_{t}\right)$ versus $\mathrm{t}$ gave a straight line, with negative intercepts. $\mathrm{K}_{1}$ and $\mathrm{q}_{e}$ values were calculated from the equation obtained from the linear graph.

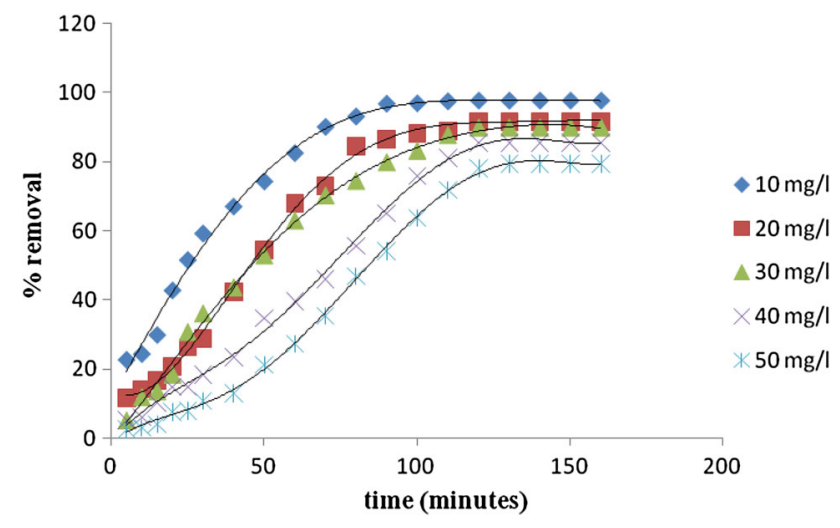

Fig. 6 Graph of CR dye percent removal onto GLAC versus adsorption time at various initial concentrations at $30{ }^{\circ} \mathrm{C}$

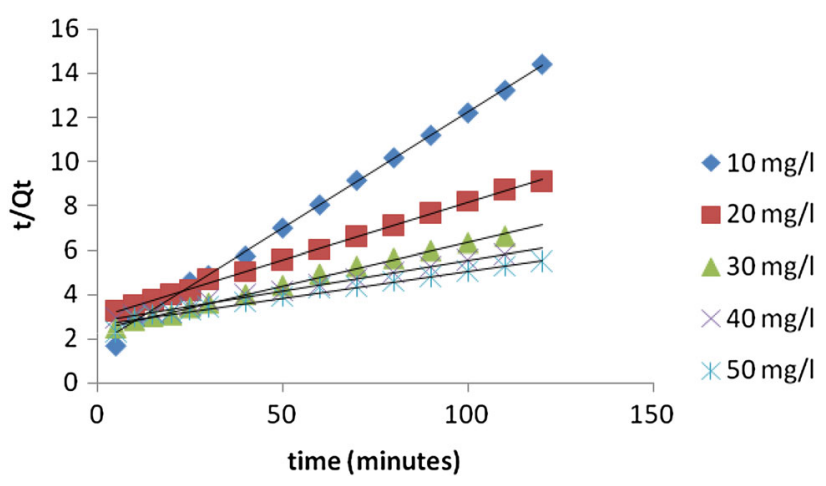

Fig. 7 Plot of pseudo-second-order kinetic model at $50{ }^{\circ} \mathrm{C}$ for $\mathrm{CR}$ dye adsorption onto GLAC

On the other hand, the plots of $t / \mathrm{q}_{t}$ versus $t$ for pseudosecond-order model were also used to study the adsorption process (Fig. 7). As can be seen from Table 9, the values of $R^{2}$ calculated for the adsorption process are higher than that obtained for pseudo-first order model. This shows that adsorption of CR onto GLAC is consistent with pseudo-second-order model. Additionally, Elovich model is used to describe the second-order kinetics by assuming that the actual solid surfaces are energetically heterogeneous. Theoretically, when there is increment in solution temperature, the extent of surface coverage, $\beta$ should decrease owning to the fact that the number of sites available for adsorption will be less at higher temperature. Unfortunately, the low values of $R^{2}$, ranging from 0.746 to 0.964 in the adsorption process shows that the experimental data did not agree with Elovich kinetic model (Dogan et al. 2007).

By comparing the values of $R^{2}$ which is closest to unity, the values of $\mathrm{R}^{2}$ for the adsorption process yielded excellent fits in the following order: pseudo-second order $>$ pseudo-first order $>$ Elovich (Table 9). 
Table 5 Isotherm parameters for CR dye adsorption onto GLAC at $30{ }^{\circ} \mathrm{C}$

\begin{tabular}{|c|c|c|c|c|c|c|c|c|c|c|c|c|c|}
\hline \multicolumn{4}{|l|}{ Langmuir } & \multicolumn{3}{|c|}{ Freundlich } & \multicolumn{3}{|l|}{ Temkim } & \multicolumn{4}{|l|}{ D-R } \\
\hline $\mathrm{q}_{m}(\mathrm{mg} / \mathrm{g})$ & $\mathrm{K}_{L}(1 / \mathrm{mg})$ & $\mathrm{R}_{L}$ & $R^{2}$ & $\mathrm{~K}_{f}$ & $n$ & $R^{2}$ & $\mathrm{~K}_{T}(\mathrm{~mol} / \mathrm{g})$ & $\mathrm{b}_{T}(\mathrm{~mol} / \mathrm{kJ})$ & $R^{2}$ & $\mathrm{X}_{m}(\mathrm{mg} / \mathrm{g})$ & $\beta\left(10^{-9}\right)$ & $E(\mathrm{~kJ} / \mathrm{mol})$ & $R^{2}$ \\
\hline 47.62 & 0.525 & 0.037 & 0.982 & 15.92 & 2.42 & 0.990 & 8.00 & 8.659 & 0.959 & 24.83 & 0.086 & 2.41 & 0.925 \\
\hline
\end{tabular}

Table 6 Isotherm parameters for CR dye adsorption onto GLAC at $40{ }^{\circ} \mathrm{C}$

\begin{tabular}{|c|c|c|c|c|c|c|c|c|c|c|c|c|c|}
\hline \multicolumn{4}{|l|}{ Langmuir } & \multicolumn{3}{|c|}{ Freundlich } & \multicolumn{3}{|l|}{ Temkim } & \multicolumn{4}{|l|}{ D-R } \\
\hline $\mathrm{q}_{m}(\mathrm{mg} / \mathrm{g})$ & $\mathrm{K}_{L}(1 / \mathrm{mg})$ & $\mathrm{R}_{L}$ & $R^{2}$ & $\mathrm{~K}_{f}$ & $n$ & $R^{2}$ & $\mathrm{~K}_{T}(\mathrm{~mol} / \mathrm{g})$ & $\mathrm{b}_{T}(\mathrm{~mol} / \mathrm{kJ})$ & $R^{2}$ & $\mathrm{X}_{m}(\mathrm{mg} / \mathrm{g})$ & $B\left(10^{-9}\right)$ & $E(\mathrm{~kJ} / \mathrm{mol})$ & $R^{2}$ \\
\hline 45.45 & 0.67 & 0.029 & 0.976 & 17.62 & 2.67 & 0.981 & 12.79 & 7.924 & 0.938 & 22.22 & -0.044 & 3.37 & 0.969 \\
\hline
\end{tabular}

Table 7 Isotherm parameters for CR dye adsorption unto GLAC at $50{ }^{\circ} \mathrm{C}$

\begin{tabular}{|c|c|c|c|c|c|c|c|c|c|c|c|c|c|}
\hline \multicolumn{4}{|l|}{ Langmuir } & \multicolumn{3}{|c|}{ Freundlich } & \multicolumn{3}{|l|}{ Temkim } & \multicolumn{4}{|l|}{ D-R } \\
\hline $\mathrm{q}_{m}(\mathrm{mg} / \mathrm{g})$ & $\mathrm{K}_{L}(1 / \mathrm{mg})$ & $\mathrm{R}_{L}$ & $R^{2}$ & $\mathrm{~K}_{f}$ & $n$ & $R^{2}$ & $\mathrm{~K}_{T}(\mathrm{~mol} / \mathrm{g})$ & $\mathrm{b}_{T}(\mathrm{~mol} / \mathrm{kJ})$ & $R^{2}$ & $\mathrm{X}_{m}(\mathrm{mg} / \mathrm{g})$ & $B\left(10^{-9}\right)$ & $E(\mathrm{~kJ} / \mathrm{mol})$ & $R^{2}$ \\
\hline 40 & 1.19 & 0.017 & 0.989 & 19.36 & 2.63 & 0.977 & 15.15 & 8.229 & 0.914 & 30.08 & -0.041 & 3.50 & 0.949 \\
\hline
\end{tabular}

Table 8 Comparison of the maximum monolayer adsorption capacities of CR dye onto various adsorbents

\begin{tabular}{lcc}
\hline Adsorbent & $\mathrm{q}_{m}(\mathrm{mg} / \mathrm{g})$ & References \\
\hline Coir pith & 6.70 & Namasivayam and Kavitha (2002) \\
Aspergillus niger biomass & 8.19 & Fu and Viraraghavan (2002) \\
Neem leaf powder & 41.20 & Bhattacharrya and Sharma (2004) \\
Bagasse fly ash & 11.89 & Mall et al. (2005) \\
Activated carbon (laboratory grade) & 1.88 & Mall et al, 2005 \\
Montmorillonite & 12.7 & Wang and Wang (2007) \\
Acid activated red mud & 7.08 & Tor and Cengeloglu (2006) \\
4-Vinyl pyridine grafted poly(ethylene) terephthalate fibers & 18.1 & Arslan (2010) \\
Aniline propylsilica xerogel & 22.62 & Pavan et al. (2008) \\
Mango leaf & 4.49 & Bello et al. (2014) \\
Spear grass & 313 & Bello and Semire (2012) \\
Ackee apple & 161.89 & Bello et al. (2013) \\
GLAC & 47.62 & This study \\
\hline
\end{tabular}

\section{Adsorption thermodynamics}

Thermodynamic parameters provide a better understanding of the effect of temperature on the adsorption process. The thermodynamic parameters are tabulated in Table 10. From the table, the negative values of $\Delta H^{\circ}$ obtained in the adsorption of CR dye onto GLAC signify the exothermic nature of the adsorption process. The $\Delta H^{\circ}$ value was found to be $-18.00 \mathrm{~kJ} / \mathrm{mol}$. The positive values of $\Delta S^{\circ}$ indicate that increase in randomness occurred at solid-solution interface during the adsorption process. This shows the affinity of adsorbent towards dye molecules (Bello et al. 2011).

As presented in Table $10, \Delta G^{\circ}$ values were negative at all studied temperatures, inferring that the adsorption was spontaneous in nature. Since the values of $\Delta G^{\circ}$ decreased with increasing temperature, it suggests that at higher temperature, the driving force was less, resulting in lower adsorption uptake (Tan et al. 2008). Furthermore, since the values of $\mathrm{E}_{a}$ obtained fall in the energy range of 4-80 kJ/mol, it confirms that the adsorption process was physisorption. 
Table 9 Parameters of the pseudo-first-order, pseudo-second-order and Elovich kinetic models together with their regression coefficients for GLAC at $50{ }^{\circ} \mathrm{C}$

\begin{tabular}{|c|c|c|c|c|c|c|}
\hline \multirow[t]{2}{*}{ Kinetic models } & \multirow[t]{2}{*}{ Parameters } & \multicolumn{5}{|c|}{ Initial dye concentrations } \\
\hline & & $10 \mathrm{mg} / \mathrm{l}$ & $20 \mathrm{mg} / \mathrm{l}$ & $30 \mathrm{mg} / \mathrm{l}$ & $40 \mathrm{mg} / \mathrm{l}$ & $50 \mathrm{mg} / \mathrm{l}$ \\
\hline \multirow[t]{4}{*}{ Pseudo-first order } & $\mathrm{K}_{1}\left(\min ^{-1}\right)$ & 0.0322 & 0.0161 & 0.0138 & 0.0115 & 0.0069 \\
\hline & $\mathrm{Q}_{e}($ experimental) $(\mathrm{mg} / \mathrm{g})$ & 9.84 & 18.79 & 28.00 & 34.50 & 43.00 \\
\hline & $\mathrm{Q}_{e}($ calculated $)(\mathrm{mg} / \mathrm{g})$ & 9.53 & 18.41 & 27.93 & 35.56 & 43.35 \\
\hline & $R^{2}$ & 0.979 & 0.991 & 0.997 & 0.991 & 0.961 \\
\hline \multirow[t]{4}{*}{ Pseudo-second order } & $\mathrm{K}_{2}\left(\min ^{-1}\right)$ & 0.00678 & 0.00088 & 0.00063 & 0.00026 & 0.000221 \\
\hline & $\mathrm{Q} e($ experimental $)(\mathrm{mg} / \mathrm{g})$ & 9.84 & 18.79 & 28.00 & 34.50 & 43.00 \\
\hline & $\mathrm{Q}_{e}($ calculated $)(\mathrm{mg} / \mathrm{g})$ & 9.52 & 19.61 & 25.64 & 37.04 & 41.67 \\
\hline & $R^{2}$ & 0.997 & 0.999 & 0.996 & 0.995 & 0.976 \\
\hline \multirow[t]{3}{*}{ Elovich } & $\beta$ & 0.389 & 0.163 & 0.108 & 0.093 & 0.079 \\
\hline & $\alpha(\mathrm{mg} / \mathrm{g} \min )$ & 1.07 & 0.97 & 1.33 & 1.19 & 1.17 \\
\hline & $R^{2}$ & 0.964 & 0.893 & 0.945 & 0.823 & 0.746 \\
\hline
\end{tabular}

\section{Diffusion mechanism}

Generally, adsorption mechanism for dye removal using an adsorbent is made up of a series of steps which involves the migration of adsorbate from aqueous phase to the solid adsorbent. In many cases, there is a probability for intraparticle diffusion to be the rate-determining step, especially in a rapidly stirred batch system.

Therefore, in order to study the rate of dye molecules adsorbed onto GLAC, another kinetic model, intraparticle

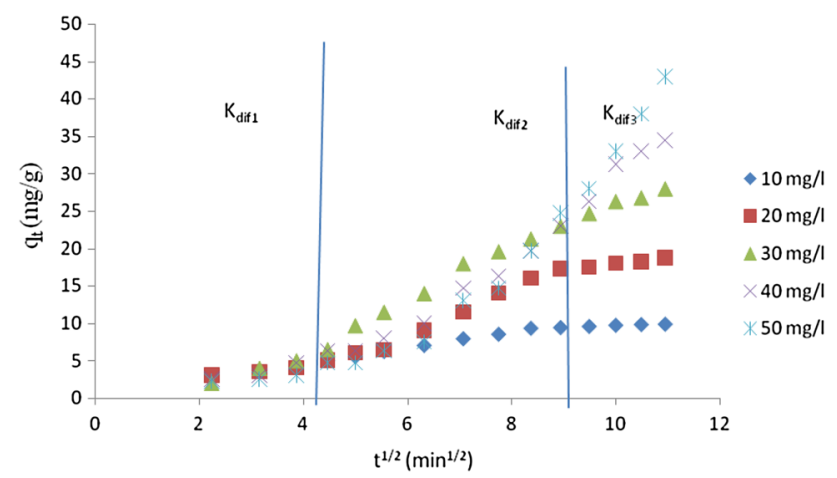

Fig. 8 Plot of intraparticle diffusion model for CR dye adsorption onto GLAC at $50{ }^{\circ} \mathrm{C}$ diffusion model was carried out. According to this model, the values of $\mathrm{q}_{t}$ were found to be linearly correlated with the value of $t^{1 / 2}$ and the rate constant, $k_{\text {diff }}$ can be directly determined from the slope of regression line.

In the present study, the plots obtained were nonlinear (Fig. 8). The first one is bulk diffusion, followed by external mass transfer resistance while the third is intraparticle mass transfer resistance. The rate of attainment to equilibrium may be controlled by particle diffusion (Yang and Al-Duri 2005). Following the fast adsorption, there was a gradual adsorption stage. At this stage, intraparticle diffusion is the rate-controlling step. Thereafter, adsorption became very slow and stable, approaching an equilibrium stage and maximum adsorption, i.e., a plateau profile. Similar findings were reported by Vimonses and coworkers (Vimonses et al. 2009). The three stages can be determined by the intraparticle diffusion rate as referred to $k_{\text {dif }}$. The increase in $\mathrm{q}_{\mathrm{t}}$ versus $t^{1 / 2}$ profiles of CR dye adsorption by GLAC adsorbents was nonlinear (Fig. 8). The deviation from the origin shows that intraparticle transport is not the only rate-limiting step. It can be seen, however, that the second adsorption stage is characterized as the intraparticle diffusion, which is the rate-controlling step for the adsorption process. The plots did not pass through the origin (i.e., $\mathrm{C} \neq 0$ ).

Table 10 Thermodynamic parameters for adsorption of CR onto GLAC

\begin{tabular}{|c|c|c|c|c|c|c|c|c|c|c|}
\hline \multirow[t]{2}{*}{ Adsorbent } & \multirow[t]{2}{*}{$\Delta H^{\circ}(\mathrm{kJ} / \mathrm{mol})$} & \multirow[t]{2}{*}{$\Delta S^{\circ}(\mathrm{kJ} / \mathrm{mol} \mathrm{K})$} & \multicolumn{3}{|c|}{$\Delta G^{\circ}(\mathrm{kJ} / \mathrm{mol})$} & \multicolumn{5}{|c|}{$\mathrm{E}_{a}(\mathrm{~kJ} / \mathrm{mol})$} \\
\hline & & & $303 \mathrm{~K}$ & $313 \mathrm{~K}$ & $323 \mathrm{~K}$ & $10 \mathrm{mg} / \mathrm{L}$ & $20 \mathrm{mg} / \mathrm{L}$ & $30 \mathrm{mg} / \mathrm{L}$ & $40 \mathrm{mg} / \mathrm{L}$ & $50 \mathrm{mg} / \mathrm{L}$ \\
\hline GLAC & -18.00 & 0.054 & -32.67 & -33.97 & -35.56 & 5.82 & 34.92 & 32.01 & 28.68 & 14.55 \\
\hline
\end{tabular}


Table 11 Parameters of the intraparticle kinetic models together with its regression coefficients for GLAC at $50{ }^{\circ} \mathrm{C}$

\begin{tabular}{lllllr}
\hline $\begin{array}{l}\text { CR initial } \\
\text { concentration }\end{array}$ & $\begin{array}{l}10 \mathrm{mg} / \\
1\end{array}$ & $\begin{array}{l}20 \mathrm{mg} / \\
1\end{array}$ & $\begin{array}{l}30 \mathrm{mg} / \\
1\end{array}$ & $\begin{array}{l}40 \mathrm{mg} / \\
1\end{array}$ & $\begin{array}{l}50 \mathrm{mg} / \\
1\end{array}$ \\
\hline$K_{\mathrm{dif} 1}\left(\mathrm{mg} / \mathrm{g} \mathrm{min}^{1 / 2}\right)$ & 0.609 & 0.609 & 2.010 & 1.349 & 0.489 \\
$K_{\mathrm{dif} 2}\left(\mathrm{mg} / \mathrm{g} \mathrm{min}^{1 / 2}\right)$ & 1.029 & 2.988 & 3.451 & 4.209 & 4.486 \\
$K_{\mathrm{dif} 3}\left(\mathrm{mg} / \mathrm{g} \mathrm{min}^{1 / 2}\right)$ & 0.248 & 0.877 & 2.235 & 5.791 & 10.260 \\
$\mathrm{C}_{1}$ & 1.616 & 1.616 & 2.477 & 0.524 & 1.104 \\
$\mathrm{C}_{2}$ & 0.476 & 9.341 & 7.601 & 15.060 & 18.170 \\
$\mathrm{C}_{3}$ & 7.198 & 9.194 & 3.446 & 28.440 & 69.50 \\
$\left(R_{1}\right)^{2}$ & 0.997 & 0.997 & 0.998 & 1.000 & 1.000 \\
$\left(R_{2}\right)^{2}$ & 0.988 & 0.994 & 0.997 & 0.997 & 0.996 \\
$\left(R_{3}\right)^{2}$ & 0.995 & 0.998 & 0.997 & 0.981 & 0.999 \\
\hline
\end{tabular}

This further indicates that the intraparticle diffusion was involved in the adsorption process, but was not the only rate-controlling step. The intercepts $\mathrm{C}$ are proportional to the boundary layer thickness. The extent of thickness of boundary layer can be examined from the $C$ value. The effect of boundary layer increases with the value of $C$ (Ozcan et al. 2005). The boundary layer also helps to determine the tendency of the adsorbent to adsorb the dye or remain in solution. Since diffusion takes place, the boundary layer is considered as a viscous drag which exists between the GLAC surface and the CR dye solution diffusing across its surface. Therefore, higher values of boundary layer thickness, C, indicate higher adsorption capacities (Table 11).

\section{Conclusions}

This study revealed the potential of activated guava leaf as an efficient precursor for the preparation of activated carbon. Activation and generation of the porous structure enhanced the adsorption process. Equilibrium studies showed that Freundlich isotherm model fit the adsorption data most, signifying that the CR dye adsorption does not form a monolayer on GLAC, it rather follows multilayer adsorption process. The pseudo-second-order kinetic model showed the best correlation for the data. Results also showed that the intraparticle diffusion occurred in the adsorption process, but was not the only rate-controlling step (Table 8). Thermodynamic parameters, i.e., the negative values of Gibbs energy and the negative value of enthalpy, indicated that the adsorption process is spontaneous and exothermic in nature.

Acknowledgments The corresponding author acknowledges the support obtained from The World Academy of Science (TWAS) in form of grant; Research Grant number: 11-249 RG/CHE/AF/ AC_1_UNESCO FR: 3240262674.
Open Access This article is distributed under the terms of the Creative Commons Attribution 4.0 International License (http:// creativecommons.org/licenses/by/4.0/), which permits unrestricted use, distribution, and reproduction in any medium, provided you give appropriate credit to the original author(s) and the source, provide a link to the Creative Commons license, and indicate if changes were made.

\section{References}

Aharoni C, Ungarish M (1976) Kinetics of activated chemisorptions. Part I: the non-Elovichian part of the isotherm. J Chem Soc Farad Trans 72:265-268

Ajemba RO (2014) Adsorption of Malachite green from aqueous solution using activated Ntezi clay: optimization. Isotherm and Kinetic Studies. Int J Eng 27:839-854

Allen SJ, Koumanova B (2005) Decolourisation of water/wastewater using adsorption. J Univ Chem Technol Metall 40:175-192

Alok M, Mittal J, Malviya A, Gupta VK (2009) Adsorption removal of hazardous anionic dye "Congo red" from wastewater using waste materials and recovery by adsorption. J Colloid Interface Sci 340:16-26

Amin NK (2008) Removal of acid blue-106 dye from aqueous solution using new activated carbons developed from pomegranate peel: adsorption equilibrium and kinetics. J Hazard Mater 165:52-62

Anthony C (2005) A review of guava (Psidium guajava). Pers Care Mag 6:33-39

Arslan M (2010) Use of 1,6-diaminohexane-functionalized glycidyl methacrylate-g-poly (ethylene terephthalate) fiber for removal of acidic dye from aqueous solution. Fiber Polym 11:177-184

Auta M, Hameed BH (2011) Optimized waste tea activated carbon for adsorption of methylene blue and acid blue 29 dyes using response surface methodology. Chem Eng J 175:233-243

Ahmad MA, Ahmad N, Bello OS (2014a) Adsorptive removal of Malachite green dye using durian seed-based activated carbon. Water Air Soil Pollut 225:2057. doi:10.1007/s11270-014-2057-z

Ahmad MA, Ahmad N, Bello OS (2014b) Modified durian seed as adsorbent for the removal of methyl red dye from aqueous solutions. Appl Water Sci. doi:10.1007/s13201-014-0208-4

Ahmad MA, Afandi NS, Bello OS (2015) Optimization of process variables by response surface methodology for malachite green dye removal using lime peel activated carbon. Appl Water Sci. doi:10.1007/s13201-015-0284-0

Baek MH, Ijagbemi CO, SJ O, Kim DS (2010) Removal of malachite green from aqueous solution using degreased coffee bean. J Hazard Mater 176:820-828

Banat IM, Nigam P, Singh D, Marchant R (1996) Microbial decolorization of textile-dye-containing effluents: a review. Bioresour Technol 58:217-227

Bello OS (2013) Adsorptive removal of malachite green with activated carbon prepared from oil palm fruit fibre by $\mathrm{KOH}$ activation and $\mathrm{CO}_{2}$ gasification. S Afr J Chem 66:32-41

Bello OS, Ahmad MA (2012) Coconut (Cocos nucifera) shell based activated carbon for the removal of Malachite green dye from aqueous solutions. Sep Sci Technol 47(6):903-912

Bello OS, Semire B (2012) Equilibrium, kinetic, and quantum chemical studies on the adsorption of Congo red using Imperata cylindrica leaf powder activated carbon. Toxicol Environ Chem 94(6):1114-1124

Bello OS, Adeogun IA, Ajaelu JC, Fehintola EO (2008) Adsorption of methylene blue onto activated carbon derived from periwinkle shells: kinetics and equilibrium studies. Chem Ecol 24:285-295 
Bello OS, Tan TS, Ahmad MA (2011) Adsorption of remazol brilliant violet-5R reactive dye from aqueous solution by cocoa pod huskbased activated carbon: kinetic, equilibrium and thermodynamic studies. Asia Pac J Chem Eng 7:378-388

Bello OS, Ahmad MA, Ahmad N (2012) Adsorptive features of banana (Musa paradisiaca) stalk-based activated carbon for malachite green dye removal. Chem Ecol 28(2):153-167

Bello OS, Auta M, Ayodele OB (2013) Ackee apple (Blighia sapida) seeds: a novel adsorbent for the removal of Congo red dye from aqueous solutions. Chem Ecol 29(1):58-71

Bello OS, Bello OU, Ibrahim OL (2014) Adsorption characteristics of mango leaf (Mangifera indica) powder as adsorbent for Malachite green dye removal from aqueous solution. CJPL 2:1-13

Bhadusha N, Ananthabaskaran T (2011) Adsorptive removal of methylene blue onto $\mathrm{ZnCl}_{2}$ activated carbon from wood apple outer shell: kinetics and equilibrium studies. J Chem 8:1696-1707

Bhattacharrya KG, Sharma A (2004) Azadirachta indica leaf powder as an effective biosorbent for dyes; a case study with aqueous Congo red solutions. J Environ Manage 71:217-229

Dada AO, Inyinbor AA, Oluyori AP (2012) Comparative adsorption of dyes unto activated carbon prepared from maize stems and sugar cane stems. J Appl Chem 2:38-43

Dogan M, Ozdemir Y, Alkan M (2007) Adsorption kinetics and mechanism of cationic methyl violet and methylene blue dyes onto sepiolite. Dyes Pigment 75:701-713

Dubinin MM (1960) The potential theory of adsorption of gases and vapors for adsorbents with energetically non-uniform surface. Chem Rev 60:235-266

Freundlich HM (1906) Over the adsorption in solution. J Phys Chem $57: 385-470$

Fu YZ, Viraraghavan T (2002) Removal of Congo red from an aqueous solution by fungus Aspergillus niger. Adv Environ Res 7:239-247

Gupta VK, Mittal A, Krishnan L, Mittal J (2006a) Adsorption treatment and recovery of the hazardous dye, Brilliant Blue FCF, over bottom ash and de-oiled soya. J Colloid Interface Sci 293:16-26

Gupta VK, Mittal A, Kurup L, Mittal J (2006b) Adsorption of a hazardous dye, erythrosine, over hen feathers. J Colloid Interface Sci 304:52-57

Gupta VK, Jain R, Varshney S (2007) Removal of reactofix golden yellow 3 RFN from aqueous solution using wheat husk-an agricultural waste. J Hazard Mater 142:443-448

Gupta VK, Mittal A, Malviya A, Mittal J (2009) Adsorption of carmoisine A from wastewater using waste materials-bottom ash and deoiled soya. J Colloid Interface Sci 335:24-33

Ho YS, McKay G (1999) Pseudo-second order model for sorption processes. Proc Biochem 34:451-465

Lagergren S (1898) Zur Theorie der sogenannten Adsorption Geloester Stoffe. Veternskapsakad Handl 24:1-39

Langmuir I (1918) The adsorption of gases on plane surfaces of glass, mica and platinum. J Am Chem Soc 40:1361-1403

Mall KG, Srivastava VC, Agarwal NK, Mishra IM (2005) Removal of Congo red from aqueous solution by bagasse fly ash and activated carbon: kinetic study and equilibrium isotherm analyses. Chemosphere 61:492-501
Mittal A, Gupta VK, Malviya A, Mittal J (2008) Process development for the batch and bulk removal and recovery of a hazardous, water-soluble azo dye (Metanil yellow) by adsorption over waste materials (Bottom Ash and De-Oiled Soya). J Hazard Mater 151:821-832

Nacera Y, Aicha B (2006) Equilibrium and kinetic modeling of methylene blue sorption by pre-treated dead Streptomyces rimosus: effect of temperature. Chem Eng J 119:121-125

Namasivayam C, Kavitha D (2002) Removal of Congo red from water by adsorption onto activated carbon prepared from coir pith, an agricultural solid waste. Dye Pigment 54:47-58

Nollet H, Roels M, Lutgen P, Meeren PVD, Verstraete W (2003) Removal of PCBs from wastewater using fly ash. Chem Eco 53:655-665

Okeola OF (1999) Preparation and characterization of activated carbon from various waste materials, M. Sc. Thesis, University of Ilorin 5:18-37

Ozcan AS, Erdem B, Ozcan A (2005) Adsorption of acid blue 193 from aqueous solutions onto BTMA activated bentonite. Colloid Surf A Physicochem Eng Asp 266:73-81

Pavan F, Dias S, Lima E, Benvenutti E (2008) Removal of Congo red from aqueous solution by anilinepropylsilica xerogel. Dyes Pigment 76:64-69

Sivaraj R, Namasivayam C, Kadirvelu K (2001) Orange peel as an adsorbent in the removal of acid violet 17 (acid dye) from aqueous solutions. Waste Manage 21:105-110

Srivastava K, Balasubramanian N, Ramakrishna TV (1988) Studies on chromium removal by rice husk carbon. Indian $\mathrm{J}$ Enviro Health 30(4):376-387

Tan IAW, Ahmad AL, Hameed BH (2008) Adsorption of basic dye using activated carbon prepared from oil palm shell: batch and fixed bed studies. Desalination 225:13-28

Temkin M, Pyzhev V (1940) Kinetics of ammonia synthesis on promoted iron catalysts. Acta physiochim URSS 12(3):217-222

Tor A, Cengeloglu Y (2006) Removal of Congo red from aqueous solution by adsorption onto acid activated red mud. J Hazard Mater 138:409-415

Vimonses V, Lei S, Jin B, Chow CWK, Saint C (2009) Adsorption of Congo red by three Australian kaolins. Appl Clay Sci 43:465-472

Wang L, Wang A (2007) Adsorption characteristics of Congo red onto the chitosan/montmorillonite nanocomposite. J Hazard Mater 147:979-985

Weber WJ, Morris JC (1962) Kinetics of adsorption on carbon from solution. J Sanit Eng Div ASCE 89:31-59

Wong Y, Yu J (1999) Laccase catalysed decolorization of synthetic dyes. Water Res 33:3512-3520

Wu RC, Qu JH, Chen YS (2005) Magnetic powder $\mathrm{MnOFe}_{2} \mathrm{O}_{3}-\mathrm{a}$ novel material for the removal of azo-dye from water. Water Res 39:630-638

Yahya SA, Musa IE, Amjad HE, Gavin MW (2008) Effect of solution $\mathrm{pH}$, ionic strength, and temperature on adsorption behavior of reactive dyes on activated carbon. Dyes Pigment 77:16-23

Yang X, Al-Duri B (2005) Kinetic modeling of liquid-phase adsorption of reactive dyes on activated carbon. J Colloid Interface Sci 287:25-34 